\title{
JOÃO DO RIO E OS AFRICANOS: RAÇA E CIÊNCIA NAS CRÔNICAS DA BELLE ÉPOQUE CARIOCA
}

\author{
Juliana Barreto Farias \\ Doutoranda em História Social pela Universidade de São Paulo (USP).*
}

\begin{abstract}
Resumo
Reverenciado como o cronista da belle époque carioca, João do Rio (1881-1921) não economizava nos comentários racistas e evolucionistas em seus textos jornalísticos e literários. Para compreender essa faceta ainda tão pouco explorada na obra do famoso jornalista, examinarei, neste artigo, um conjunto de reportagens sobre religiosidades, festas e costumes africanos, publicadas na imprensa carioca nos anos de 1904 e 1905.
\end{abstract}

\section{Pallavras-chave}

Rio de Janeiro • João do Rio $•$ africanos $\bullet$ raça.

\section{Abstract}

Although he was revered as the belle époque chronicler of Rio de Janeiro, João do Rio's chronicles and fiction are filled with racist comments. To understand this yet little explored facet in the work of the famous journalist, I will examen a series of reports on African beliefs, celebrations, and customs published in Rio de Janeiro's press during the years 1904 and 1905.

\section{Keywords}

Rio de Janeiro • João do Rio • Africans • race.

* Bolsista do CNPq. Agradeço as leituras generosas feitas por Lilian Schwarcz e Maria Cristina Wissenbach a uma primeira versão deste texto. 
Em 11 de maio de 1912, João do Rio publicou um pequeno texto, meio escondido na segunda página da Gazeta de Notícias, rebatendo um editorial divulgado pelo jornal $A$ Noite no dia anterior. Travestido de Joe, um dos seus muitos pseudônimos, criticava o tom "excessivamente indignado" do artigo que girava em torno da história de um empresário esperto, que andava contratando artistas negros e mulatos brasileiros para tocar, cantar e dançar maxixe nos boulevards de Paris. Para os editores d'A Noite, a empreitada musical era, na verdade, uma "torpe exploração", que só iria desmoralizar "nosso nome na Europa". Músicos e dançarinos nacionais desfilariam uniformizados por ruas e cafés-concertos, servindo à "gulosa curiosidade pública parisiense", que "forçosamente os aclamará como aclamaria um bando de macacos amestrados". ${ }^{1}$

João do Rio não conhecia o tal "capitalista" e nem tampouco sabia de seus reais objetivos. Mas pedia licença para discordar do patriotismo reivindicado pela folha concorrente. Em primeiro lugar, acreditava que, no continente europeu, "dos Pirineus para cima”, não havia quem tivesse pelos "negros nenhuma repulsa e há negros que representam sua pátria melhor que muito branco". E o empresário decerto estava mais preocupado em ganhar dinheiro do que em propagandear o Brasil. Tanto ele como os artistas, "sejam brancos, pretos, amarelos ou azuis", queriam mesmo era "trabalhar sua vida". Além do mais, se os parisienses tomassem o Chocolat, "clown americano e preto", como os Estados Unidos, ou o cantor de modinhas Geraldo, pelo Brasil, "seria uma calamidade desagradável para a França se alguém se lembrasse de pensar que a França é, por exemplo, o tablado do Palace-Theatre". ${ }^{2}$

Certamente temos aqui um dos raros momentos em que o famoso jornalista carioca sai em defesa de negros e mulatos. É certo que, lá pelo final do texto, ele deixa escapar que aquele grupo de artistas não representava exatamente o Brasil. Ainda assim, é uma postura bem diferente daquela que costumamos observar em suas crônicas sobre as religiões e os costumes de africanos e seus descendentes que viviam no Rio de Janeiro de princípios do século XX. Ao mirar seus "olhos de civilizado" para esse outro lado da capital carioca, João do Rio não economizava nos comentários depreciativos e racistas. ${ }^{3}$ E nisso estava de

1 Uma empresa diabólica. A Noite, 10 de maio de 1912, p. 1.

2 Patriotismo. Coluna O Instante, Gazeta de Notícias, 11 de maio de 1912, p. 2. Cf. RODRIGUES, João Carlos. João do Rio: uma biografia. Rio de Janeiro: Topbooks, 1996, p. 143-144.

3 Ao assistir uma cerimônia num dos muitos candomblés do Rio, João do Rio diz que, "diante de meus olhos de civilizado", passavam negros e negras enfeitados e fantasiados. RIO, João 
acordo com muitos de seus contemporâneos. Naquela sociedade que abolira a escravidão há tão pouco tempo, as teorias raciais - já praticamente em desuso na Europa - acomodavam-se muito bem aos ambientes científicos e literários. ${ }^{4}$ Por isso mesmo, não causava estranheza, por exemplo, os adjetivos usados por Sílvio Romero para (des)qualificar o crítico José Veríssimo: "tapuio matreiro"; "cafuso decadente"; "feioso caboclo".5

No caso de João de Rio, chama atenção que as ideias racistas e evolucionistas que permeavam parte de sua produção literária e jornalística ainda continuem tão pouco exploradas. Reverenciado como o cronista do Rio de Janeiro da belle époque, ele ainda parece ocupar um lugar ambíguo nas análises sobre cultura e religiosidades "negras". Muniz Sodré e Luis Filipe de Lima, por exemplo, comparam as informações sobre cerimônias de candomblé e outras práticas ditas africanas apresentadas em suas crônicas com relatos mais recentes, como o do oluô Agenor Miranda. Desse confronto, concluem que os textos de $A s$ religiões no Rio são, na verdade, um amontoado de enganos e dados duvidosos, que mais veiculam preconceitos da sociedade branca da época do que informam sobre os cultos. ${ }^{6}$

Já o biógrafo João Carlos Rodrigues procura, ao questionar a "existência ou não do racismo" na obra do jornalista, avaliar se o próprio João do Rio - filho de uma mulata - se considerava negro. Observando fotografias de infância e mocidade, encontra uma criança de "aparência branca", que se transforma num adolescente "fortemente amulatado, de cabelos cacheados". Monteiro Lobato chegou mesmo a dizer que ele usava o "corte escovinha" para disfarçar o "pixaim". Rodrigues não localizou qualquer foto ou caricatura com esse tipo

do. As religiões no Rio. Apresentação de João Carlos Rodrigues. Rio de Janeiro: José Olympio, 2006, p. 53.

4 Cf. CORRÊA, Mariza. As ilusões da liberdade: a escola Nina Rodrigues e a antropologia no Brasil. 2 ed. revista. Bragança Paulista: Editora da Universidade de São Francisco, 2001, p. 49. SCHWARCZ, Lilia Moritz. Usos e abusos da mestiçagem e da raça no Brasil: uma história das teorias raciais em finais do século XIX. Afro-Ásia, 18, 1996, p. 97. SCHWARCZ, Lilia Moritz. O espetáculo das raças. Cientistas, instituições e questão racial no Brasil (1870-1930). São Paulo: Companhia das Letras, 1993.

5 CORRÊA, op. cit., p. 52. A autora ressalta que talvez não tenha sido por acaso que alguns intelectuais da passagem do século, que explicitamente combateram o racismo em suas obras, como Lima Barreto e Manuel Bonfim, tenham sido ridicularizados enquanto viviam e excluídos das instituições que formal ou informalmente tinham algum significado de aceitação de seu papel.

6 LIMA, Luís Felipe de e SODRÉ, Muniz. Um vento sagrado. História de vida de um adivinho da tradição nagô-Ketu brasileira. Rio de Janeiro: Mauad, 1996, p. 63-74. 
de corte. Pelo contrário, constatou que, ainda jovem, João do Rio foi ficando careca. Por outro lado, acredita ser bastante verossímil a versão de que sua foto oficial para a Academia Brasileira de Letras foi muito retocada, principalmente o nariz, "de perfil acintoso".

Diante dessas evidências, o pesquisador reconhece que o cronista não se considerava negro, nem mesmo pelo "condescendente conceito brasileiro". O que fica nítido em As religiões no Rio, em que só se refere aos africanos e seus descendentes na terceira pessoa: são "eles" (os "pretos ululantes"; "negros degenerados") em oposição a "nós" (que têm avós "portugueses de boa fibra"). Sem contar ainda que, fora José do Patrocínio (que era seu contraparente), ele praticamente não teve amigos ou fez referências e elogios aos negros e mulatos "bem-sucedidos" com quem conviveu. O exemplo mais conhecido é o escritor Lima Barreto, a quem João do Rio nunca dedicou uma linha sequer, nem mesmo depois de ter sido atacado no romance Recordações do escrivão Isaías Caminha. ${ }^{7}$ Não obstante esse distanciamento pessoal e o abuso de expressões pejorativas em suas reportagens, Rodrigues considera - em texto mais recente - que estamos longe de um preconceito mais específico. ${ }^{8}$ Para o biógrafo, os pesquisadores mais militantes devem se calar, em vez de julgar escritos de 1904 pelos conceitos do século XXI, com acusações de "negro de alma branca", "dedo-durismo" das classes desfavorecidas e outros "radicalismos que beiram uma asneirada". 9

Nem descartar totalmente as informações apresentadas em sua obra, nem amenizar o racismo latente em seus escritos. Para compreender como João do Rio retratou as "diferentes raças", especialmente a dos "negros", na cidade do Rio de inícios do século XX, só mesmo perscrutando seus textos, no tempo e no lugar em que foram produzidos. Partindo do sistema analítico proposto por Antonio Candido, é possível examinar essa produção do repórter-cronista num movimento interligado que envolve autor, texto, contexto e público. ${ }^{10}$ Para tanto, tomarei como base as famosas reportagens sobre as "religiões africanas", escritas em fevereiro e março de 1904 e mais tarde reunidas no livro As religiões no Rio, e textos inéditos sobre festas, costumes e participação de africanos no mercado de

\footnotetext{
RODRIGUES, João Carlos. João do Rio, op. cit., p. 144-145.

8 RODRIGUES, João Carlos. Apresentação. In: RIO, João do. As religiões no Rio. Rio de Janeiro: José Olympio, 2006, p. 11.

9 Idem.

${ }^{10}$ CANDIDO, Antonio. Formação da literatura brasileira: momentos decisivos 1750-1880. $11^{\circ}$ ed. Rio de Janeiro: Ouro sobre Azul, 2007, p. 25-37.
} 
trabalho carioca, preparados também em 1904 e no ano de $1905 .{ }^{11}$ Outros registros impressos, como notas e matérias jornalísticas publicadas no período, e fontes bibliográficas, em especial, biografias e estudos sobre a obra de João do Rio, serão igualmente fundamentais para a análise que pretendo desenvolver aqui.

\section{$\mathbf{O}$ cronista e a cidade}

Nascido Paulo Emílio Cristóvão Barreto (1881-1921), o repórter da Gazeta fez-se Paulo Barreto por profissão e, com a fama, foi feito João do Rio. Como tantos literatos e jornalistas de sua época, assumia identidades diversas nos textos que publicava em jornais e revistas. Foi Claude, nas críticas de arte, X., nas crônicas cotidianas, e ainda Joe e José Antonio José. Só que nenhum desses pseudônimos ficou tão colado a sua personalidade e obra como João do Rio, ${ }^{12}$ numa simbiose entre cidade e obra, reconhecida por seus próprios contemporâneos, como mostra o texto de Ribeiro Couto que saiu no Correio Paulistano, logo após a morte do autor em junho de 1921.

O Rio de Janeiro vive na obra de Paulo Barreto. A cidade foi variando de alma e de fisionomia, mas o escritor acompanhou-a, a todos os instantes. Sua obra é reflexo da vida carioca e 20 anos de civilização em marcha. Nos seus livros está essa vida vertiginosa, com suas vaidades, as suas virtudes, os seus vícios, a sua loucura, o seu lirismo, os seus ridículos, os seus tédios, os seus entusiasmos, a sua dor, a sua beleza. $[\ldots]^{13}$

Filho único de pai positivista e republicano extremado (o gaúcho Alfredo Coelho Barreto, professor de matemática do Colégio Pedro II) e de mãe mulata (dona Florência), João do Rio cresceu numa casa da rua do Hospício (atual Buenos Aires), num tempo em que a cidade do Rio já contava mais de 700 mil

\footnotetext{
${ }^{11}$ As reportagens sobre as religiões da cidade do Rio foram reunidas em livro em dezembro de 1904. Em 2006, a obra foi relançada, com apresentação de João Carlos Rodrigues. Tomei esse livro como base para a análise, mas também procurei cotejar esses textos com os artigos originais que saíram na Gazeta. Essa metodologia se mostrou muito frutífera, já que - como veremos adiante pude acompanhar toda a repercussão da publicação daqueles textos entre os leitores, os africanos da cidade e os próprios jornalistas. Outras crônicas sobre os africanos, ainda inéditas, foram transcritas do jornal Gazeta de Notícias, e da revista Kosmos. Cf. S. João entre os africanos. Gazeta de Notícias, 25 de junho de 1904; O natal dos africanos. Kosmos, dezembro de 1904; Afoché. Gazeta de Notícias, 2 de março de 1905; Negros ricos. Gazeta de Notícias, 13 de maio de 1905.

${ }^{12}$ O'DONNELL, Julia. De olho na rua: A cidade de João do Rio. Rio de Janeiro: Jorge Zahar Editor, 2008.

${ }^{13}$ Citado em MAGALHÃeS JUNIOR, Raimundo. A vida vertiginosa de João do Rio. Rio de Janeiro: Civilização Brasileira, 1978, p. 348.
} 
habitantes. ${ }^{14}$ Segundo Rodrigues, há diversas evidências do envolvimento de sua família com a campanha da Abolição, como a "velha avó perdulária que gastava o que não tinha para alforriar escravos alheios". ${ }^{15} \mathrm{E}$ foi justamente por meio do jornalista e abolicionista José do Patrocínio, dono d'A Cidade do Rio e seu contraparente, que ele iniciou sua vida jornalística.

Com 18 anos incompletos já tinha escrito seu primeiro artigo para A Tribuna, uma crítica da peça Casa de boneca, de Ibsen. Mas foi na gazeta de Patrocínio que estabeleceu uma colaboração mais regular, que durou até pelo menos o final de 1900. Depois disso, escreveu, entre janeiro de 1901 e março de 1902, para os jornais $O$ Paiz, O Dia e O Correio Mercantil. Nesses primeiros tempos de imprensa, portava-se como uma espécie de "paladino do Realismo e do Naturalismo", investindo contra os românticos e, sobretudo, contra os simbolistas. Era também muito rigoroso com os literatos nacionais, só elogiando mesmo Aluízio de Azevedo e Adolfo Caminha. Em artigo publicado n'A Cidade do Rio, em agosto de 1899, dizia que a função dos escritores seria "plantar convincentemente o Naturalismo, o realismo d'Arte no torrão mole e indolente do Brasil com toda a nossa alma moça de 20 anos", nem que para que isso precisasse aparecer de "chicote na mão". "Nós, os moços que se batem pela reação naturalista", continuava em seu radical manifesto, "queremos o socialismo, mesmo pelos mais violentos métodos como uma erupção primária da Anarquia, à bomba" ${ }^{16}$

Em novembro de 1903, ingressaria na Gazeta de Notícias e contribuiria, de forma decisiva, para a renovação do jornalismo carioca. Desde a década de 1870, a imprensa brasileira vinha passando por um rápido processo de transformação. As pequenas folhas diárias - quase sempre ligadas a grupos políticos, organizadas em modestas estruturas de produção e sem pretensões de atingir um público mais amplo - perdiam, aos poucos, espaço para os "grandes jornais", que passam a ser montados como empresas comerciais. ${ }^{17}$ Ao adotar padrões mais modernos de produção, esses novos periódicos buscavam atrair um número

\footnotetext{
${ }^{14}$ CARVALHO, José Murilo. Os bestializados. O Rio de Janeiro e a República que não foi. $3^{\mathrm{a}}$ ed. São Paulo: Companhia das Letras, 1987, p. 16-17.

${ }^{15}$ RODRIGUES, João Carlos. João do Rio: uma biografia, op. cit., p. 25.

${ }^{16}$ O realismo. A Cidade do Rio, 31 de agosto de 1899, p. 2. Cf. RODRIGUES, op. cit., p. 33.

${ }^{17}$ Outras mudanças e inovações, como o crescimento e a dinamização da vida urbana, o considerável aumento da população, a expansão das camadas médias, a ampliação e renovação de centros de ensino e o desenvolvimento do sistema de comunicações (estrada de ferro, telégrafo, navegação a vapor), também contribuíram para essa modernização da imprensa. Ver: BARBOSA, Marialva. Os donos do Rio. Imprensa, poder e público. Rio de Janeiro: Vício de Leitura, 2000.
} 
maior de leitores, multiplicando suas pautas e interesses e assumindo claramente um papel civilizatório. Assistia-se, assim, a uma verdadeira ampliação da função e da influência social que a imprensa havia adquirido na Regência, "o primeiro grande momento do jornalismo brasileiro", num processo sem paralelo nos dias de hoje. ${ }^{18}$ Machado de Assis, por diversas vezes, registrou essa transformação, afirmando que o jornal se tornara "o grande veículo do espírito moderno"; uma "coisa que fez tremer as aristocracias, mais do que os movimentos populares". ${ }^{19}$ José Alencar também captou as mudanças, dizendo, numa crônica de 1875, que "não se lê muito entre nós; mas a opinião do jornal é acatada". ${ }^{20}$

Para Nelson Werneck Sodré, o surgimento da Gazeta de Notícias, em 1874, foi um marco decisivo nesse processo, conferindo novo ritmo ao jornalismo na capital do Império. Além de inaugurar um sistema de vendas avulsas pela cidade, seu preço baixo, os textos de fácil leitura e a introdução de novos recursos gráficos e jornalísticos, como o uso de manchetes, subtítulos, reportagens e caricaturas, logo a transformaram no diário mais importante da cidade, modelo a ser seguido por outros jornais, como O Paiz e Diário de Notícias. ${ }^{21}$ Comandada por Ferreira de Araújo, era o favorito da elite cultural e tinha, entre seus colaboradores, "os mais bem pagos da imprensa nacional", como os escritores Coelho Neto, Olavo Bilac e Emílio de Menezes.

Quando ingressou ali, o jovem Paulo Barreto escrevia na coluna "A cidade", como o misterioso X., comentando fatos cotidianos e, por vezes, recorrendo a diálogos irônicos ao estilo de Arthur Azevedo. ${ }^{22}$ No final de 1903, apareceria com um novo nome na reportagem "O Brasil lê": João do Rio. Nem poderia imaginar que essa alcunha suplantaria sua verdadeira identidade. Depois de realizar entrevistas com diplomatas portugueses, italianos e japoneses sobre o tema da imigração, publicaria, nos meses de fevereiro e março de 1904, as famosas reportagens sobre As religiões no Rio. Como veremos em detalhes

\footnotetext{
${ }^{18}$ MELLO, Maria Tereza Chaves de. A república consentida: cultura democrática e científica do final do Império. Rio de Janeiro: Editora da FGV/Edur, 2007, p. 79. Cf. LUSTOSA, Isabel. Insultos impressos: a guerra dos jornalistas na Independência (1821-1823). São Paulo: Companhia das Letras, 2000.

${ }^{19}$ Citado em SODRÉ, Nelson Werneck. História da imprensa no Brasil. $4^{\mathrm{a}}$ ed. Rio de Janeiro: Mauad, 1999.

${ }^{20}$ Citado em COUTINHO, Afrânio (org.). A polêmica Alencar-Nabuco. Rio de Janeiro: Tempo Brasileiro, 1965, p. 39.

${ }^{21}$ SODRÉ, op. cit., p. 224-226.

${ }^{22}$ RODRIGUES, op. cit., p. 43.
} 
mais adiante, a repercussão desses textos alçou o autor à condição de grande jornalista. Num momento em que o "Rio civilizava-se", com as reformas comandadas pelo prefeito Pereira Passos, o repórter mostrava facetas nada civilizadas da capital federal.

Gilberto Freyre, em Ordem e progresso, coloca os artigos sobre as religiões no Rio, mais tarde publicados em livro, ao lado de obras como Os sertões, de Euclides da Cunha, O abolicionismo, de Joaquim Nabuco, e Canaã, de Graça Aranha, por conta da "caracterização do mesmo Brasil, como não de um tempo só, mas de vários, esses às vezes contraditórios". Para o autor pernambucano, $\mathrm{o}$ material reunido sobre as múltiplas religiosidades cariocas "talvez deva ser considerado o maior triunfo na arte da reportagem até hoje alcançado em língua portuguesa, com sucesso não apenas jornalístico, mas literário, até sociológico". ${ }^{23}$

Em estudo recente, Júlia O’Donnell ressalta que essas reportagens são o melhor exemplo do temperamento etnográfico que caracterizava a obra de João do Rio. Como nas análises antropológicas "clássicas", o jornalista também realizava uma "observação participante", com uma prolongada convivência entre os "nativos" e a adoção de informantes locais. Conduzindo o repórter por territórios desconhecidos, esses personagens revelavam lugares e pessoas que, na condição de outsider, ele não poderia conhecer sozinho. Ao expor esses guias conhecedores dos códigos, da geografia e da rede de sociabilidades dos espaços visitados, o cronista conferia a seus escritos, como propõe a autora, o "carimbo do 'saber local', garantindo a verossimilhança do relato". Numa narrativa cheia de detalhes e sensações, descrevia sua chegada a campo - os diversos centros religiosos - com o mesmo sabor das notas etnográficas a partir das quais os antropólogos registram suas construções sobre o observado. ${ }^{24}$

Saindo do gabinete e mergulhando na nova realidade de sua cidade, João do Rio dava uma guinada que mudaria definitivamente as práticas da imprensa brasileira. Inaugurando um jornalismo investigativo, o cronista-repórter, que também flertava com a ficção, ganhava as ruas da capital federal, percorrendo desde as "vielas do vício" até as altas rodas sociais. Como um "radical de ocasião", na classificação de Antonio Candido, não tinha um compromisso com a revolução, pelo contrário, muitas vezes era mesmo contra ela. Contudo, em

\footnotetext{
${ }^{23}$ FREYRE, Gilberto. Ordem e progresso. Rio de Janeiro: Nova Aguilar, 2000, p. 72.

${ }^{24}$ O'DONNELL, Julia. De olho na rua: A cidade de João do Rio. Rio de Janeiro: Jorge Zahar Editor, 2008, p. 103-109.
} 
algum período ou apenas num instante de sua vida, fez alguma coisa pela pobre gente: uma palavra, um ato, uma assinatura, um auxílio ou um artigo, como o que defendeu, em 1912, os negros e mulatos brasileiros que apresentariam seu maxixe em Paris. ${ }^{25}$

\section{"É preciso saber quem mostrou o segredo!"}

(Gazeta de Notícias, 13/03/1904).

Os "feiticeiros" e as mães-de-santo do Rio de Janeiro estavam em "polvorosa" no início de março de 1904. Inconformados com as revelações que a Gazeta de Notícias vinha fazendo, decidiram se reunir, na tarde do dia 13, na casa do africano Emanuel Ojô. Reconhecido como o "chefe de uma espécie de maçonaria geral dos negros", esse "preto elegante, que fala inglês e decide nos momentos de perigo" ia descobrir quem era Antonio, o africano de Lagos que estava abrindo as "cenas incríveis" do culto dos pretos minas. ${ }^{26}$

Durante três meses, Antônio teria guiado o repórter da Gazeta pelas casas das ruas de São Diogo, Barão de São Félix, Hospício, Núncio e da América, onde se realizavam os candomblés e viviam os pais-de-santo, alufás [líderes muçulmanos] e "feiticeiros" da cidade do Rio. No dia 9 de março, foi publicada a primeira reportagem de uma série de cinco artigos que revelavam os segredos de suas práticas religiosas. Era mais um capítulo do inquérito sobre as religiões no Rio que João do Rio realizara no início daquele ano. Cultos evangélicos, judaicos, maronitas, satânicos, além de fisiólatras, cartomantes e integrantes da igreja positivista foram investigados. Os leitores, tão curiosos quanto o próprio jornalista, garantiram o sucesso da série. Como era grande a procura pelos artigos, havia dias em que a edição da Gazeta de Notícias esgotava-se em pouco tempo, sendo "impossível servir por completo aos muitos pedidos que chegam diariamente". ${ }^{27}$

E os textos sobre o desconhecido "mundo dos feitiços" foram justamente os que mais chamaram a atenção dos cariocas. Além de provocar tamanha agitação entre os africanos que se viram retratados nas páginas do jornal, alguns proprie-

\footnotetext{
${ }^{25}$ CANDIDO, Antônio. Literatura e sociedade. São Paulo: Nacional, 1980, p. 83. O’DONNELL, op. cit., p. 52.

${ }^{26}$ Gazeta de Notícias, 13 de março de 1904; 20 de março de 1904.

${ }^{27}$ Gazeta de Notícias, 9 de abril de 1904.
} 
tários de casas de fonógrafos andaram procurando Antônio, interessados em fixar e reproduzir as cantigas africanas. Ao ser encontrado, o "negro de Lagos" recusou a oferta, receoso de que a "máquina que fala, ofendesse os orixalás" ${ }^{28}$ Em 16 de março de 1904, a Gazeta estampou, em sua primeira página, uma ilustração - provavelmente de autoria do caricaturista Raul Pederneiras ${ }^{29}$ - retratando duas "feiticeiras" envoltas em panos da Costa e adornadas por colares e grossas argolas. Uma delas, a que aparenta ser mais velha, estaria instruindo, com "orações do rito", uma "candidata ao sacerdócio". Nessa mesma edição, João do Rio descreveria o "mais terrível mistério da religião dos minas": o egum ou evocação das almas. ${ }^{30}$

\section{NO RURDO DOS FERTIGOS}

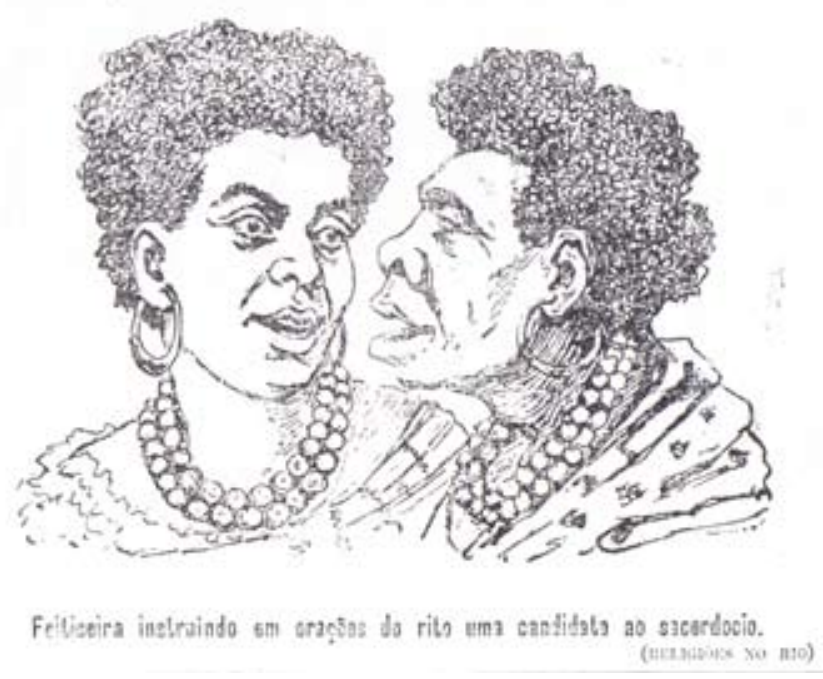

\footnotetext{
${ }^{28}$ Gazeta de Notícias, 10 de março de 1904, p. 1.

${ }^{29}$ Não há qualquer menção, no jornal, sobre a autoria da ilustração. Mas, comparando os desenhos de 1904 com um painel de caricaturas registrado no álbum Cenas da vida carioca, de Raul Pederneiras, de 1924, intitulado "A mulher progride", no qual ironizava sem piedade as aspirações feministas do início do século XX, há uma "baleira" com traços bem semelhantes às feiticeiras. E o próprio caricaturista compôs, em dezembro de 1904, uma capa colorida para o livro que reuniu as reportagens publicadas na Gazeta no início daquele ano. Cf. Gazeta de Noticias, 4 de dezembro de 1904.

${ }^{30}$ Gazeta de Notícias, 16 de março de 1904, p. 2. O egum ou evocação das almas é uma cerimônia ritual em que as almas dos ancestrais mortos voltam à Terra.
} 
Tal foi a curiosidade despertada que, em 20 de março, a Gazeta de Notícias publicou uma "Galeria de feiticeiros", com retratos e pequenas biografias de três dos "mais temíveis exploradores da credulidade pública": os africanos de Lagos, Emannuel Ojô e Abubaca Caolho, este veio para o Brasil como carregador, mas acabou vivendo exclusivamente da feitiçaria; e ainda Zebinda, negra cartomante, que gostava de dar festas, danças e candomblés. Não foi nada fácil conseguir retratar essas três personagens, já que "o feiticeiro não tira nunca o retrato, para não ser vítima do feitiço em imagem”. Sem o auxílio do negro Miguel, que indicou ao fotógrafo do jornal alguns pretos para as instantâneas, não seria possível traçar a fisionomia e certamente o breve perfil desses "temíveis feiticeiros". ${ }^{31}$ Vejamos, por exemplo, como foi descrita a trajetória de Ojô:

É filho de um relojoeiro na África, em Lagos. Mais ou menos rico, mas perdulário, polígamo, gastando muito, andando sempre a cavalo, era o preto elegante, o príncipe de Sargan de carapinha. Quando o cobre diminuiu, fez-se trabalhador de estiva e nem um seu parente, rei de uma tribo do interior, rei dos Ifé, conseguiu minorar-lhe as agruras. Ojô, que entre os ingleses é Schmidt, não acreditava muito em feitiço, temendo-o, entretanto. Nesse estado de ceticismo, o negro comprava os feitiços novos, todas as inovações da alquimia africana. Um dia, cansado de trabalhar, veio para o Brasil, onde aprendeu o alicuri dos alufás. Todos o respeitam e dizem-se seus parentes. [...] Ojô é o consultor técnico dos pretos; na sua casa é que se dão as reuniões dos feiticeiros, que se resolvem as contendas, que se escrevem as cartas, que se resolve quem há de morrer. $[\ldots]^{32}$

A ideia parecia ser mesmo destacar flashes da vida deles na África, a prática da feitiçaria e suas relações com a comunidade africana do Rio. Havia, igualmente, a preocupação em acentuar traços físicos ou sinais diacríticos que, muitas vezes, evidenciavam sua filiação étnica. Como é possível notar nos retratos de Abubaca e Ojô, seus rostos eram marcados pelas escarificações típicas dos iorubás, no Rio de Janeiro conhecidos como pretos minas. Essas marcas, chamadas de alajas no continente africano, eram feitas ainda na infância, com lâminas afiadas manipuladas por especialistas, geralmente devotos de Ogum. ${ }^{33}$

\footnotetext{
${ }^{31}$ Galeria de feiticeiros. Gazeta de Notícias, 20 de março de 1904, p. 5.

${ }^{32}$ Idem.

${ }^{33}$ REIS, João José. Rebelião escrava no Brasil. A história do levante dos malês em 1835. São Paulo: Companhia das Letras, 2003 (edição revista e ampliada), p. 311-313.
} 

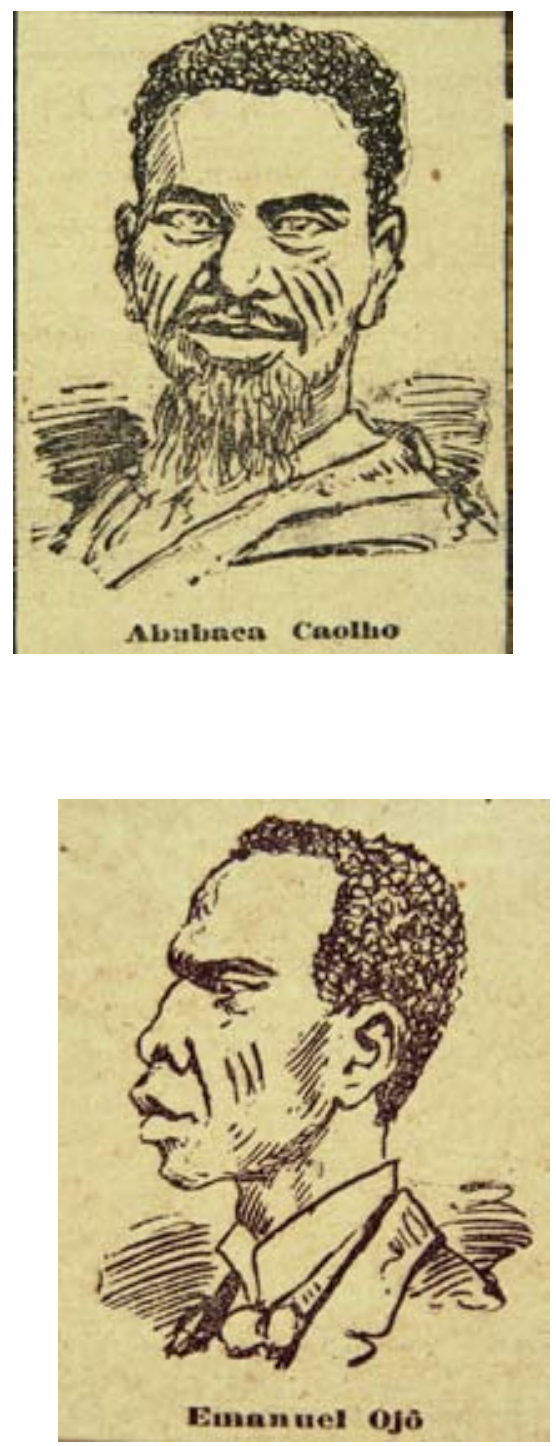

Quase um mês antes, a Gazeta havia começado a publicar uma outra coleção de perfis. Em 27 de fevereiro, a "Galeria do crime" trazia o primeiro retrato, acompanhado de pequena biografia, de um dos assassinos que viraram "celebridades" na capital federal. Para os editores do periódico, havia amplo interesse em conhecer as fisionomias desses "facínoras", já que, como mostra- 
va a "escola de Lombroso", os "criminosos degenerados" constituíam "ampla matéria de estudo" e podiam ser "corrigidos". ${ }^{34}$

Desde pelo menos fins do século XIX, as ideias do italiano Cesare Lombroso (1836-1909) já influenciavam intelectuais e cientistas brasileiros, como o médico maranhense Nina Rodrigues. ${ }^{35}$ Principal expoente da antropologia criminal, Lombroso acreditava que a criminalidade era um fenômeno físico e hereditário que podia ser verificado, de forma objetiva, em diferentes sociedades. Através da criação de toda uma taxionomia de traços faciais e corporais, os estigmas, considerava possível detectar o que subsistia de nossos ancestrais nos homens e mulheres contemporâneos, levando-os ao crime e à loucura. Segundo Mariza Corrêa, essa nova concepção penal e política levou a um deslocamento crucial na questão da responsabilidade. A liberdade da vontade, a disposição de atuar conscientemente em determinada maneira ou direção, já não era mais relevante para se julgar um ato ou analisar um acontecimento. $\mathrm{O}$ comportamento de cada pessoa estava, de antemão, definido pela pertinência a certas "classes biológicas”, que, pesquisadas e definidas primeiramente em prisões e hospícios, acabaram sendo estendidas à sociedade como um todo. ${ }^{36}$

Seguindo de perto essas proposições, a Gazeta de Notícias buscava, com a publicação do primeiro retrato de sua galeria, mostrar como "as feições desse preto são bem características, como característico é a alcunha que lhe deram: moleque bode". A partir de um resumo de sua trajetória, ficamos sabendo que Bode, ou Manuel Cardoso dos Passos, começou a vida como marinheiro, mas já nesse tempo seus "maus instintos" se manifestaram. Bastava observar as diversas cicatrizes que cobriam seu corpo, fruto dos castigos provocados por seus atos de indisciplina. Daí em diante, não abandonou mais o mundo do crime.

[...] teve afinal baixa e de marinheiro transformou-se em secretario de cocheiro de carro. Uma vez arrombou a porta de uma casa vazia e aí penetrou com um menor. Sobre o

\footnotetext{
${ }^{34}$ Galeria do crime. Gazeta de Notícias, 27 de fevereiro de 1904, p. 2.

${ }^{35}$ CORRÊA, op. cit., p. 68-72. Mariza Corrêa destaca que, com as críticas ao determinismo estreito de Lombroso, Nina Rodrigues acabou incorporando outras perspectivas teóricas a seus escritos, mas não abandonou a suposição básica da hereditariedade como destino, o que informava os trabalhos do pesquisador italiano e seus seguidores, e que, em maior ou menor grau, era compartilhada por quase todos os cientistas da época. Lilia Schwarz também destaca como as ideias de Lombroso foram adotadas por médicos peritos da Faculdade de Medicina da Bahia, especializados no estudo da mente do criminoso. À frente desse movimento, estava Nina Rodrigues, professor da escola e ferrenho defensor da medicina legal. SCHWARCZ, op. cit., p. 209-215.

${ }^{36}$ CORRÊA, op. cit., p. 70.
} 
que aí se passou não devemos insistir. Esse arrombamento custou a Bóde um processo. Submetido a júri, este condenou-o a oito anos de prisão. Bode tem, aliás, vivido constantemente ora na Detenção, ora nos xadrezes das delegacias, tantas as desordens que provoca. Também esteve preso na cadeia de Petropolis, de onde se pode concluir que não foi para veranear que subiu àquela cidade. $\mathrm{O}$ seu primeiro assassinato foi cometido em 1901. Bode, com uma facada, matou o procurador do Club dos Celibatários, Lima Roma. Desta vez, o júri condenou-o a 24 anos de prisão. Achando que era muita coisa, Bode apelou para novo júri. Na detenção, onde se acha, Bode tem tido bom comportamento, o que talvez seja plano. Esse criminoso tem hoje 35 anos. ${ }^{37}$

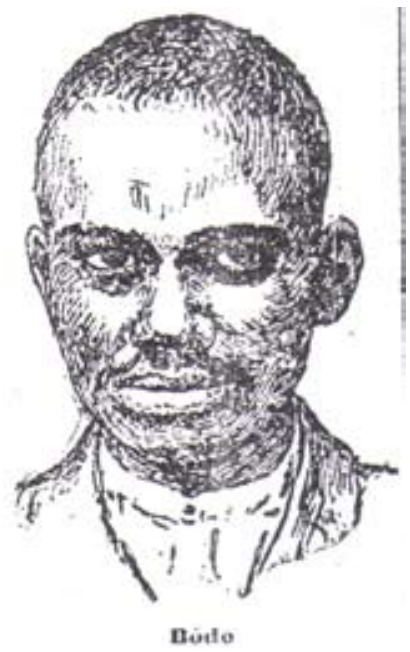

Pelo que se depreende deste relato, Bode - um "preto" cheio de cicatrizes - parecia predestinado a esse comportamento por um impulso congênito. Embora o texto não apresente outros traços corporais ou faciais que atestem essa herança maldita, à maneira lombrosiana, os leitores podiam constatar a propensão à delinquência no seu retrato de "feições bem características". Num processo simbiótico, texto e imagem informavam que atos como aqueles eram, naturalmente, cometidos por indivíduos com aquela fisionomia. ${ }^{38}$

\footnotetext{
${ }^{37}$ Galeria do crime. Gazeta de Notícias, 27 de fevereiro de 1904, p. 2.

${ }^{38}$ A mesma estratégia usada para retratar a vida de Bode foi adotada nos perfis de José do Senado e Cardosinho, publicados logo em seguida na "Galeria do crime".
} 
Tanto esse perfil de Bode, como os de José do Senado, Cardosinho e outros assassinos famosos foram publicados na mesma época em que saíram as reportagens de João do Rio e a "Galeria de feiticeiros". Não à toa, traziam características em comum. Em primeiro lugar, as duas coleções de retratos seguiam exatamente a mesma diagramação. Além disso, as imagens e os pequenos artigos não tinham a autoria identificada. É bem provável que João do Rio tenha tido alguma participação na redação dos textos. Ojô, Abubaca Caolho e Zebinda eram personagens constantemente mencionadas em seus artigos. No caso dos criminosos, as evidências são um pouco mais diretas. Em 1908, o cronista visitou a Casa de Detenção ("escola de todas as perdições e de todas as degenerescências") e conversou com vários dos homens e mulheres presos ali. Percorrendo as "galerias", encontrou "negros degenerados", "mulatos com contrações de símios", jovens prostitutas, poetas, malandros da Saúde, "menores gatunos". Ao se deparar com José do Senado, teria ouvido do detento: "É com a imprensa que eu conto. O senhor foi cruel, porque não sabia...."39 De fato, em 15 de março de 1904, o "assassino" da rua do Senado havia figurado na "Galeria do crime" da Gazeta. Depois de descrever uma vida de contendas, mortes e prisões, o redator - o próprio João do Rio? - encerrara suas notas dizendo que aquele "tipo de moleque pernóstico" já estava "um tanto alquebrado, pelos feitos do crime e pela vida do cárcere. [...] Quem o vir no cubículo ou a passar pelas vastas galerias da Casa de Detenção, não reconhece nele o antigo José do Senado esperto, ágil e rápido no salto de costas". ${ }^{40}$

Também chamava a atenção a semelhança fisionômica entre feiticeiros e criminosos. Ainda que o ilustrador - certamente o mesmo nas duas galerias - tenha tido o cuidado de realçar certas particularidades, como as marcas de "nação" de Ojô e Abubaca, e o terno usado por José do Senado, os formatos de bocas, narizes e olhos mostravam-se bem similares. Não se deve descartar, é claro, a possibilidade de que José do Senado e Emanuel Ojô fossem mesmo muito parecidos. Só que a maneira com que os quadros das séries foram apresentados - quase que intercalados entre uma galeria e outra - decerto induzia os leitores a fazerem uma rápida associação entre os negros facínoras e assassinos incorrigíveis e os alufás, mães-de-santo e feiticeiros. Como veremos

\footnotetext{
${ }^{39}$ RIO, João do. A alma encantadora das ruas. Rio de Janeiro: Secretaria Municipal de Cultura, Dep. Geral de Doc. e Inf. Cultural, 1987, p. 162.

${ }^{40}$ Galeria do crime - Os assassinos. José do Senado. Gazeta de Notícias, 6 de março de 1904, p. 4.
} 
mais adiante, a aproximação desses líderes religiosos com o crime, a loucura, a embriaguez e outras práticas ditas "degeneradas" também era uma constante nas crônicas de João do Rio.

Por ora, cabe ressaltar ainda que a repercussão dos textos sobre os minas levou o jovem jornalista da Gazeta a realizar novas incursões pelas casas de africanos. Quando flanava por uma "rua sossegada" do centro da cidade, numa tarde de junho de 1904, reencontrou o "fiel e dedicado Antônio". Sem hesitar, aceitou o convite de seu guia para participar dos festejos juninos que se realizariam na casa do Galiza Vavá, experiência mais tarde descrita na crônica "S. João entre os africanos", publicada no dia 25 daquele mês. Lá constatou - não sem um certo espanto - como os candomblés celebravam tanto S. João, como S. Pedro e o 2 de julho, data em que se comemorava a independência na Bahia. ${ }^{41}$ Seis meses depois, decidiu conhecer de perto as festividades promovidas pelos africanos durante o período natalino. Não se sabe muito bem onde assistiu a tais cerimônias, talvez em algumas das "escuras casas das ruas do Hospício, Barão de S. Félix, Costa, S. Diogo, S. Jorge”. No relato da visita divulgado na revista Kosmos de dezembro, João do Rio demonstrava todo seu assombro com aquela festa de natal que se estendia por quase trinta dias, só terminando com "a apoteose do Senhor do Bonfim". ${ }^{42}$

Ainda no final de 1904, os textos do inquérito sobre as religiões no Rio foram reunidos e editados em livro produzido na Europa, com a ordem das reportagens habilmente alterada. Os registros sobre os cultos africanos, publicados, primeiramente, no meio da série, passavam a figurar como artigos iniciais, atestando seu grande sucesso. ${ }^{43} \mathrm{O}$ volume de 300 páginas tinha capa colorida, ilustrada pelo caricaturista Raul, e portraites charges feitas por Gil. Como informava a Gazeta, as vendas haviam começado no dia 5 de dezembro, na Livraria Garnier, à rua do Ouvidor, exatamente às 10 horas da manhã. No final da tarde, 200 exemplares já tinham sido comprados. De São Paulo e Minas Gerais vinham, pelo telégrafo, pedidos de remessa de volumes. Em 15 de dezembro, a primeira edição já estava quase esgotada. ${ }^{44} \mathrm{Em}$ seis anos, a obra chegou a vender mais de

\footnotetext{
${ }^{41}$ RIO, João do. S. João entre os africanos. Gazeta de Notícias, 25 de junho de 1904, p. 1.

${ }^{42}$ RIO, João do. O natal dos africanos. Kosmos, dezembro/1904.

${ }^{43}$ RODRIGUES, João Carlos. João do Rio: uma biografia. Rio de Janeiro: Topbooks, 1996, p. 52.

${ }^{44}$ Cf.: Gazeta de Notícias, 04/12/1904; 05/12/1904; 13/12/1904 e 15/12/1904.
} 
oito mil exemplares, um verdadeiro best-seller, numa época em que o público leitor e comprador de livros era bem reduzido. ${ }^{45}$

Disputados por leitores e repudiados pelos africanos, os artigos agradaram críticos e cientistas. Na Gazeta de Notícias, o cronista que assinava como O. B. dizia que, a cada período, a cada vocábulo, revelava-se uma surpresa. "Imaginase um mundo de cenas. E quando se começa a ler é tal o exotismo da narração que mal se reprime um movimento de assombro. Essa poderosa qualidade do imprevisto é a característica de João do Rio. Fê-lo grande. Ainda maior o há de fazer". ${ }^{46} \mathrm{O}$ médico-legista Afrânio Peixoto, então diretor do Hospital de Alienados, enviou carta à redação, felicitando o jornalista pelo lançamento, que acabava de ser incorporado à biblioteca da instituição. Esperava, sinceramente, que os estudiosos pudessem rastrear naquele "belo livro" o "processo psicológico de vesânias aqui tratadas. Eis, pois, como teu inquérito de vida carioca tem uma aplicação científica: talvez nem de todos suspeitada". ${ }^{47}$ Quase três anos depois, seu "valor antropológico" seria reconhecido pela Comissão de História do Instituto Histórico e Geográfico Brasileiro, então composta por Sílvio Romero (amigo de João do Rio) e pelo visconde de Ouro Preto. No parecer, datado de 20 de maio de 1907, destacavam que:

O livro As religiões no Rio do sr. Paulo Barreto é único em seu gênero na literatura brasileira. Nós já possuímos, por certo, vários quadros de costumes, principalmente no romance, no drama, na comédia e em obras de viagem; não possuímos, porém, um quadro social, tão palpitante de interesse, como esse que o jovem dedicou às crenças religiosas do Rio de Janeiro. Não é um livro, nem o seu autor se propôs a fazê-lo, de alta indagação crítica ou histórica sobre credos e teologia, ao gosto de Baurr, Strauss, Wald, Michel, Nicolas, Colani, Reville e outros, mas um apanhado em flagrante de várias crenças confessionais existentes nesta capital, nas suas práticas culturais.

Escrito em verve, graça e cintilação de estilo, o livro é uma verdadeira joia que deve ser apreciada pelos leitores competentes. Tem cunho histórico, porque fotografa o es-

\footnotetext{
${ }^{45}$ A tiragem total considerada satisfatória para um livro de prosa, por exemplo, era de 1.000 exemplares. Cf. O'DONNEL, op. cit., p. 75. GOMES, Renato Cordeiro. João do Rio: vielas do vício, ruas da graça. Rio de Janeiro: Relume-Dumará, Prefeitura do Rio, 1996, p. 67. Já João Carlos Rodrigues diz que o livro vendeu dez mil exemplares. RODRIGUES, João Carlos. Apresentação. In: RIO, João do. As religiões no Rio, op. cit., p. 7.

${ }^{46}$ Gazeta de Notícias, 19 de dezembro de 1904, p. 1.

${ }^{47}$ Gazeta de Notícias, 15 de dezembro de 1904, p. 1.
} 
tado d'alma fluminense num período de sua evolução. $\mathrm{O}$ autor merece um lugar neste Instituto. $^{48}$

Houve ainda quem dissesse que o livro levaria a novas ondas de repressão na cidade. Desde 1890, com a promulgação do novo Código Penal republicano, casas de culto e terreiros de candomblé sofriam com investidas policiais. Frequentes já em princípios do século XIX, essas batidas tornaram-se ainda mais rigorosas com a criação de três artigos específicos que puniam o curandeirismo, a falsa medicina e a magia. ${ }^{49}$ De fato, algumas das personagens descritas por João do Rio tornaram-se alvos constantes da justiça e da polícia. Mas antes mesmo da publicação de suas reportagens. Em 1895, por exemplo, Zebinda da Costa, "negra cartomante" apresentada na "Galeria de feiticeiros", foi presa em flagrante e processada como incursa no artigo 157 do Código, acusada de realizar consultas "para despertar sentimentos de amor e ódio, subjugando a credulidade pública". ${ }^{50}$

Se não incitaram novas detenções, os textos sobre os minas acabaram estimulando a imprensa a descobrir mais feiticeiros, divulgando em pequenas notas suas prisões e até mesmo seus enterros. Em 6 de dezembro de 1904, o Jornal do Commércio falava do cerco que havia sido dado à casa do africano Manoel Gomes, vulgo Manoel dos Figos, onde se realizavam "sessões de feitiçaria com grande concorrência". Além de relatar a prisão de Manoel e de mais 20 pessoas que ali se achavam, enumerou os diversos animais e objetos "suspeitos" apreendidos, como um bode e duas galinhas pretas, pele de cobra e "varas de guiné". ${ }^{51}$ Três dias depois, a Gazeta noticiava a morte do "tremendo feiticeiro Apotijá", rememorando pequenas passagens da história deste africano que saíra de Lagos por volta de 1897, onde havia sido "escravo de um outro negro chamado Salvador". Chegara ao Brasil desejando trabalhar como carregador, mas acabou, como seus patrícios, na feitiçaria. ${ }^{52}$ E João do Rio também não

\footnotetext{
${ }^{48}$ Revista do IHGB, 1907. No mês de agosto daquele ano, João do Rio seria admitido como sócio correspondente por falta de vagas como sócio efetivo. O'DONELL, op. cit., p. 111.

${ }^{49}$ Sobre a criação desses artigos e sua aplicação, ver os trabalhos: MAGGIE, Yvonne. Medo do feitiço: relações entre magia e poder no Brasil. Rio de Janeiro: Arquivo Nacional, 1992; GUIMBELLI, Emerson. O cuidado dos mortos: uma história da condenação e legitimação do espiritismo. Rio de Janeiro: Arquivo Nacional, 1997.

${ }^{50}$ Cf. Arquivo Nacional. Processo contra Zebinda da Costa Braga, n. 435, cx. 1957; GUIMBELLI, op. cit.; Galeria de feiticeiros. Gazeta de Notícias, 20 de março de 1904, p. 5.

${ }^{51}$ Jornal do Commercio, 6 de dezembro de 1904.

${ }^{52}$ O feiticeiro Apotijá. Gazeta de Notícias, 9 de dezembro de 1904, p. 2. Para mais detalhes sobre
} 
ficou de fora dessa onda. No início de 1905, relatou a visita que fez, junto com o "feiticeiro Benzinho Bambochê, aos ranchos e cordões carnavalescos da Saúde e da Cidade Nova. Dois meses depois, encerrou seu ciclo africano, com uma crônica reveladora sobre os negros que ficaram ricos antes mesmo da Abolição. ${ }^{53}$

\section{Raça e ciência nas crônicas da belle époque}

Em quase todas as análises sobre As religiões no Rio, comenta-se que a principal inspiração do autor teria sido a série de reportagens publicadas no Le Figaro por Julés de Bois, e editadas - em 1898 - no volume intitulado Le petites réligions de Paris. As duas obras seguiam uma mesma estrutura: o narrador visita templos e sacerdotes de religiões desconhecidas na grande cidade. Rodrigues, no entanto, diz que há mais diferenças do que semelhanças entre elas, o que confirmaria a versão do próprio João do Rio, segundo a qual a ideia da série era de seu amigo Victor Viana. O pesquisador também consegue detectar influências dos romances decadentistas, como os de Huysmans, em alguns textos, o da missa negra, por exemplo. ${ }^{54}$

Afora essas referências, Júlia O'Donnell lembra que, na mesma época, Nina Rodrigues também realizava incursões etnográficas, para "uso clínico", nos terreiros e casas das populações africanas da Bahia. Não obstante essa coincidência temporal e temática, não havia qualquer menção à leitura de um pelo outro, ainda que o contato de ambos com suas obras fosse bem provável. Em 1894, Rodrigues já havia publicado As raças humanas e a responsabilidade penal no Brasil, em que defendia a proeminência do médico na atuação penal e a existência de dois códigos no país (um para os negros e outro para os brancos), em consonância com os diferentes graus de evolução das raças. ${ }^{55}$ Dez anos depois, João do Rio e Nina Rodrigues divulgariam artigos na mesma edição da revista Kosmos: enquanto o carioca falava sobre o "natal dos africanos", o

a trajetória de Apotijá e outros africanos de Lagos, ver: FARIAS, Juliana Barreto. Descobrindo mapas dos minas: trabalho urbano, alforrias e identidades, 1800-1915. In: FARIAS, J. B., GOMES, Flávio S. e SOARES, Carlos Eugênio L. No labirinto das nações: africanos e identidades no Rio de Janeiro. Rio de Janeiro: Arquivo Nacional, 2005.

${ }^{53}$ RIO, João do. Afoché. Gazeta de Notícias, 2 de março de 1905, p. 1-2; Negros ricos. Gazeta de Notícias, 13 de maio de 1905, p. 3.

${ }^{54}$ RODRIGUES, op. cit., p. 50. O’DONNELL, op. cit., p. 103. GOMES, op. cit.

${ }^{55}$ SCHWARCZ, Lilia. Usos e abusos da mestiçagem e da raça no Brasil, op. cit., p. 96. 
médico maranhense publicava um texto sobre as línguas e as belas artes que sobreviviam entre os negros. ${ }^{56}$

Para O’Donnel, as correspondências entre os dois paravam por aí. O cronista do Rio tinha seu olhar voltado para os múltiplos mundos das ruas da capital carioca, sem se ater a um objeto ou objetivos científicos definidos como Nina Rodrigues..$^{57}$ João do Rio não tinha mesmo tais pretensões, mas nem por isso descartava as teorias que circulavam pelos meios literários e acadêmicos de sua época. Ainda mais num país em que a moda cientificista era divulgada por meio da literatura e não da ciência mais diretamente. Como destaca Lilia Schwarcz, as personagens dos romances eram, muitas vezes, condicionadas pelas máximas deterministas e os enredos, diretamente inspirados nos princípios de Darwin e Spencer e nas conclusões pessimistas das teorias raciais de fins do século XIX. ${ }^{58}$

Do interior de suas instituições científicas ou simplesmente a partir de interpretações e leituras mais apressadas de textos e manuais, acadêmicos, políticos e literatos brasileiros aderiam a modelos evolucionistas, sobretudo o desgastado (na Europa) ideário social-darwinista, tomando o estudo das raças e a verificação de sua contribuição singular como objetos centrais. ${ }^{59}$ Só que, como adverte Schwarcz, não se tratava de simplesmente reconstituir o debate

${ }^{56}$ Kosmos, dezembro de 1904.

${ }^{57}$ O'DONNELL, op. cit., p. 94.

${ }^{58}$ SCHWARCZ. O espetáculo das raças, op. cit., p. 32.

${ }^{59}$ Segundo Lilia Schwarcz, a partir de 1859, especialmente com a publicação da obra $A$ origem das espécies, de Charles Darwin, estabeleceram-se as bases para a afirmação de uma espécie de paradigma de época: o conceito de evolução. Rapidamente expressões como "sobrevivência do mais apto", "adaptação", "luta pela sobrevivência", usadas pelo naturalista inglês, escaparam do terreno restrito da biologia e ganharam espaço nas demais ciências sociais. Recuperando as máximas do cientista, autores conhecidos como "darwinistas sociais" reafirmavam o caráter essencial das raças, qualificando as diferenças entre elas e transformando-as em objeto de estudo, de ciência. Paralelamente, firmava-se a escola "evolucionista social", que marcava, nesse contexto, os primórdios da antropologia. Representada por teóricos como Morgan, Frazer e Tylor, concebia o desenvolvimento humano a partir de etapas fixas e predeterminadas, e ainda vinculava de maneira mecânica elementos culturais, tecnológicos e sociais. Como numa imensa pirâmide, a humanidade dividia-se em estágios distintos, que iam da selvageria à barbárie e desta para a civilização. Nesse gradiente, os brancos - europeus - ocupavam, incontestavelmente, a supremacia. SCHWARCZ, Lilia. O espetáculo das raças, op. cit.; Usos e abusos da mestiçagem no Brasil, op. cit. Sobre Darwin e também sobre discussões anteriores a ele, ver os trabalhos de GOULD, Stephen Jay. Darwin e os grandes enigmas da vida. São Paulo: Martins Fontes, 1987; A falsa medida do homem. 2 ed. São Paulo: Martins Fontes, 2003. 
original ou o contexto de sua produção. A ideia era adaptar o que "combinava" e descartar o que parecia estranho. ${ }^{60}$

Mesmo com todas as implicações negativas, essas teorias eram usadas como argumentos decisivos para a fixação das diferenças sociais. Adotando formulações originais, esses "homens de ciência" acomodariam modelos cujas procedências teóricas eram bem diversas. Assim, aproveitariam o suposto da diferença entre as raças e sua natural hierarquia propostos pelo darwinismo social. Sem, contudo, problematizar os resultados negativos da miscigenação. Do evolucionismo social, destacariam a noção de que as raças humanas não ficam sempre estacionadas, estando, na verdade, em constante evolução e aperfeiçoamento. Porém, no caso brasileiro, ficava de fora a ideia de que a humanidade era uma só. Dessa forma, encontravam, "em teorias formalmente excludentes", usos e apropriações inusitados e concomitantes. E, pouco a pouco, esses modelos de difícil aceitação local iam se transformando em teorias de sucesso. ${ }^{61}$

João do Rio não era um cientista, mas, à sua maneira, também selecionava e ajustava algumas dessas ideias a seus objetivos. Explicitamente, ou de forma mais subentendida, elas perpassavam tanto os artigos sobre a "feitiçaria" dos minas, como outros de seus registros sobre os costumes africanos. Para começar, o jornalista parecia não ter dúvidas de que estava lidando, nestes casos, com homens e mulheres de "raças inferiores". O Xico Mina até podia se vestir como João do Rio e os seus - com "ternos brancos e suíças cortadas rentes" - mas não tinha como escapar de seu "cérebro restrito de africano". Sanin, um negro mina forte, de 40 anos, também trazia do centro da África "a capacidade poética daquela gente de miolos torrados". Por sua vez, as iaôs (negras filhas-de-santo dos candomblés), em sua "inaudita selvageria", representavam as grandes "demoníacas e farsistas da raça preta". A história de cada uma delas, "quando não é sinistra pantomima, é um tecido de fatos cruéis, anormais, inéditos, feitos de

${ }^{60}$ SCHWARCZ, Lilia. O espetáculo das raças, op. cit., p. 41.

${ }^{61}$ SCHWARCZ, Lilia. O espetáculo das raças, op. cit., p. 18-19. Em seu livro, Lilia Schwarcz mostra como, a partir da década de 1870 , essas teorias raciais passaram a ser longamente adotadas no país, sobretudo nas instituições de pesquisa e ensino brasileiras, como as faculdades de Medicina e Direito e os Institutos Históricos e Geográficos. Ao fazer um inventário dessas teorias e suas apropriações no Brasil, a autora também ressalta que, desde pelo menos o século XVIII - antes, portanto, da emergência do conceito de raça (que é de inícios do século XIX) -, a questão da diferença ou da desigualdade entre os homens já animava as discussões de filósofos e cientistas sobre o continente americano, como nas obras do conde Buffon e do abade Corneille de Pauw (SCHWARCZ, op. cit., p. 44-46). 
invisível, de sangue e de morte". E, num processo de animalização, dizia que seus "turvos antros de bruxedos" estavam abarrotados de "gorilas manhosos" e "negras aterrorizadas" que "uivavam". ${ }^{6}$

Além disso, as características físicas desses africanos explicavam muitos dos seus comportamentos morais e sociais. Em praticamente todos os textos sobre esses homens e mulheres procedentes da Costa ocidental, João do Rio estabelece uma incômoda correlação entre o cheiro dos corpos e as formas de sobrevivência e convívio social. Lendo os registros em conjunto, fica a impressão de que o odor que emanava dos poros de suas peles se espraiava e contaminava quase todos os lugares em que viviam ou por onde transitavam. Veja-se, por exemplo, sua descrição de uma visita aos cordões carnavalescos da Cidade Nova:

Quem diria, vendo na terça-feira gorda, uma ronda feroz de negros suados, esfregando os tamborins e xequeres, vestido de belsutinas sujas, trazendo nos braços cobras enroscadas, lagartos e jabotis, que essa ronda fétida, nascida na África, é a irmã gêmea das festas de Dionísio e do carnaval das aldeias medievais? [...] Deus misericordioso! Como estudando o atrasado cérebro africano admira a gente a escassa inventiva humana! $!^{63}$

As festas natalinas, realizadas nos terreiros de candomblés, também lhe causaram impressões semelhantes:

Nas fétidas chumbregas das vielas centrais, nas baiúcas escuras, onde os feiticeiros prosperam com quatro e cinco mulheres, desde o dia quinze os atabaques e os xequeres destilam no corpo das filhas-de-santo a loucura e enfurecem de saudade os velhos babaloxás. ${ }^{64}$

Ao propor uma arqueologia dos sentidos do transeunte carioca do início do século XX, Júlia O’Donnell busca nos corpos que habitam as crônicas de João do Rio sinais da introspecção do urbano como um modus vivendi. No diagnóstico dessas sensações, percebe que o olfato, apesar de fugidio e subjetivo, permite uma aproximação com uma dada conjuntura social. O estranhamento provocado pelos gases expelidos dos automóveis é exemplar nesse sentido. Classificando o novo veículo como "aquela máquina que cheira mal", o escritor explicita a necessidade do uso de recursos sensoriais na referência a objetos estranhos ao

\footnotetext{
${ }^{62}$ Cf. RIO, João do. Os feiticeiros; As iaôs. In: As religiões no Rio, op. cit., p. 29, 36, 50, 85. S. João entre os africano. Gazeta de Notícias, 25 de junho de 1904, p. 1.

${ }^{63}$ Afoché. Gazeta de Notícias, 2 de março de 1905, p. 1-2.

${ }^{64}$ O natal dos africanos. Kosmos, dezembro de 1904.
} 
seu universo de significações. ${ }^{65} \mathrm{O}$ repertório de fragrâncias citadinas evocado pela autora não inclui o cheiro (mal) inspirado pelo cronista nos corpos e lares negros. Talvez porque esses habitantes igualmente estranhos a seu universo não pudessem, ao contrário de carros, poeiras e perfumes (exemplos citados pela pesquisadora), ser incorporados àquela cidade que se modernizava. Africanos "catinguentos" e suas "baiúcas infectas e nauseabundas" eram parte de um passado que se queria apagar.

Mas, para João do Rio, os corpos dessa "ronda fétida, nascida na África" poluíam tanto os ambientes físicos, como a própria moral daqueles homens e mulheres. Como já destaquei anteriormente, a associação entre "raça preta", crime, loucura, embriaguez e prostituição era constante em seus textos sobre os africanos. A reportagem sobre as iaôs, episódio das Religiões no Rio, é recheada de relações desse tipo. Segundo o jornalista, essas mulheres

[...] abundam nesta Babel da crença, cruzando-se com a gente diariamente, sorriem aos soldados ébrios nos prostíbulos baratos, mercadejam doces nas praças, às portas dos estabelecimentos comerciais, fornecem ao hospício a sua cota de loucura, propagam a histeria entre as senhoras honestas e as cocotes, exploram e são exploradas, vivem da crendice e alimentam o caftismo inconsciente. ${ }^{66}$

Em outro texto do inquérito, conta que, ao final da visita que fez ao mina Sanin, abriu a carteira e convenceu o "feiticeiro" de que todas as suas "fantasias, arrancadas ao sertão da África" não valiam o prazer de as vender bem. Dito isso, concluiu: "Dinheiro, mortes e infâmia: as bases desse templo formidável do feitiço". ${ }^{67}$

Para alguns cientistas brasileiros, "degenerescências" como essas eram próprias dos indivíduos mestiços. Num texto de 1895, Nina Rodrigues verifica como a população mestiça da pequena cidade de Serrinha, na Bahia, tinha essa tendência. Entre aquele "povo decadente e esgotado", "a propensão às doenças mentais, às afecções graves do sistema nervoso, à degenerescência física e psíquica é das mais acentuadas". ${ }^{68}$ Nos artigos de João do Rio selecionados aqui,

\footnotetext{
${ }^{65}$ O’DONELL, op. cit., p. 143-154.

${ }^{66}$ RIO, João do. As iaôs. In: As religiões no Rio, op. cit., p. 36. No texto sobre o natal dos africanos, diz que, durante vinte e oito dias, "a fantasia africana cria um outro carnaval e a cachaça faz delirar de luxúria e pavor a tropa dos estranhos fetiches. [...] A cachaça rola de boca em boca, tornando-os inconscientes, as negras em moda batem as varas, suando, as vestes desfeitas, enquanto os ogãs sacodem os instrumentos selvagens". O natal dos africanos. Kosmos, dezembro de 1904.

${ }^{67}$ Idem. Os novos feitiços do Sanin. In: As religiões no Rio, op. cit., p. 86-87.

${ }^{68}$ RODRIGUES, Nina. Mestiçagem, degenerescência e crime. Lyon, 1899 (mimeo.)
} 
quase não se fala sobre mestiços ou mulatos, talvez porque o foco fosse mesmo os africanos. Ainda assim, nas poucas vezes em que são mencionados, eles estão, de alguma forma, em meio a práticas "degeneradas". Mas seu comportamento não parece tão desabonador como o dos africanos. Como no relato de uma cerimônia de egungum, em que boa parte das mulheres presentes pertencia ao mundo da prostituição: brancas, "meretrizes de grandes rodelas de carmim nas faces"; "mulatas em camisa, mostrando os brancos com desenhos e iniciais em azul dos proprietários do seu amor" e algumas negras, "inteiramente nuas com os seios pendentes e a carapinha cheia de banha". Já na visita que fez ao cordão do Rosa Branca, o repórter da Gazeta observou que, durante o ensaio, era proibido fumar, conversar com as damas e beber. Só que, para um "mulato carioca deixar de fazer essas três coisas, é preciso um grande respeito pela instituição". ${ }^{69}$

Não havia dúvidas: na hierarquia racial apresentada pelo cronista carioca, homens e mulheres procedentes da África ocupavam, naturalmente, o lugar mais baixo. Mas, como ele indicava, os próprios africanos também construíam suas diferenciações. A partir de seus registros, é possível avaliar que, entre os mil africanos que ainda viviam na cidade em 1904, havia, de um lado, um grupo que reunia os chamados negros minas e, de outro, aquele em que estavam os chamados "cambindas". ${ }^{70}$ Os primeiros falavam um mesmo idioma, o eubá, ${ }^{71}$ tinham alguns costumes e práticas religiosas em comum, moravam nas freguesias centrais e quase sempre exerciam ofícios como quitandeiros, carregadores ou "feiticeiros". ${ }^{72}$ Para o segundo grupo, não há descrições tão detalhadas. Segundo

${ }^{69}$ Cf. RIO, João do. A casa das almas. In: As religiões no Rio, op. cit., p. 69; Afoch. Gazeta de Notícias, 2 de março de 1905, p.1-2.

${ }^{70}$ Ao longo de todos os textos publicados na Gazeta, João do Rio sempre se refere a esses africanos como cambindas, e não como cabindas. Sobre os cabindas, como eram conhecidos os africanos embarcados no porto de Cabinda, ao norte do rio Zaire, ver: KARASCH, Mary. A vida dos escravos no Rio de Janeiro. São Paulo: Cia das Letras, 2000, p. 51-53; FARIAS, Juliana B.; GOMES, Flávio S. \& SOARES, Carlos Eugênio L. Primeiras reflexões sobre travessias e retornos: africanos cabindas, redes do tráfico e diásporas num Rio de Janeiro atlântico. Dossiê: História atlântica. Textos de História. Brasília: UnB, vol. 12, n. 1/2, 2004, p. 65-105.

${ }^{71}$ O termo eubá, certamente, era uma corruptela do termo iorubá, ou o modo como João do Rio entendera. No Grande dicionário da língua portuguesa de Antônio de Morais Silva, o eubá é identificado como o "o nome duma língua muito falada pelos negros do Rio, que deriva do egbá, nome do povo africano", "tribo de indígenas da África ocidental inglesa". Embora recorra ao relato de João do Rio para exemplificar a utilização do termo, Silva acrescenta que a língua era falada por um grupo étnico específico, os egbás de Abeokutá, também genericamente identificados como iorubás, ou como nagôs em Salvador. SILVA, Antônio de Morais. Grande dicionário da língua portuguesa. 10ª ed. Editorial Confluência, 1945, vol. IV, p. 212, 956.

${ }^{72}$ FARIAS, Juliana B. Ardis da liberdade: trabalho urbano, alforrias e identidades. In: SOARES, 
Antonio, informante de João do Rio, os cabindas não só ignoravam o eubá, como desconheciam a própria língua. "Quando os cambindas falam, misturam todas as línguas..." Só não sabemos - e nem Antonio contou - que línguas seriam essas.

Na crônica sobre a iniciação das iaôs, o cronista revela outras divergências entre as duas "nações" africanas. Durante a cerimônia, seu guia se apressa em esclarecer que aquele ritual só ocorria entre os orixás, isto é, entre os negros minas que recriavam aqui na diáspora as religiões dos orixás. Entre os cabindas, tudo ocorria de forma muito "ordinária”, já que "essa gente copiava os processos dos outros de tal forma que as cantigas de suas festas têm pedaços em português". Além disso, para "aqueles pretos sem-vergonha" - continuava o africano de Lagos - qualquer pedra, paralelepípedo ou lasca de pedreira servia para seus santos. João do Rio confessa ter ficado atônito com as revelações, concluindo que, diante de tudo isso, "positivamente achava muito inferiores os cambindas". Ao que Antonio, taxativo, complementou: "por negro cambinda é que se compreende que o africano foi escravo de branco. Cambinda é burro e sem vergonha!". ${ }^{73}$

Mais do que propriamente conhecer quem eram os cabindas que viviam no Rio de princípios do século XX, os textos do repórter da Gazeta permitem perceber as desavenças em que Antonio - e, de resto, os africanos de sua "nação" - estavam envolvidos, em especial no campo religioso. Para Wagner Silva, fica nítido "nas palavras de Antonio que a diferenciação entre o rito nagô e o rito banto resulta de um processo de construção de contrastes que se dá nitidamente nos campos das religiões afro-brasileiras", quando uma tradição tenta se impor às outras, partindo de valores selecionados, como a noção de pureza original, que legitimariam um grupo sobre os outros. ${ }^{74}$ Embora em nenhum momento João do Rio ou seu informante usem os termos nagô e banto para designar os rituais, de fato havia ali uma tentativa de legitimar determinadas práticas e depreciar outras, afirmando, dessa forma, a própria identidade étnica daqueles grupos. Os cambindas eram somente "mais ou menos" diferentes dos outros africanos. Eram "ignorantes", "burros sem-vergonhas", segundo o negro de Lagos, porque misturavam

Mariza de Carvalho (org.). Rotas atlânticas da diáspora africana: da Baía do Benin ao Rio de Janeiro. Niterói: Eduff, 2007, p. 225-256.

${ }^{73}$ RIO, João do. Os feiticeiros; As iaôs. In: As religiões no Rio, op. cit., p. 20, 39-40.

${ }^{74}$ SILVA, Wagner Gonçalves da. Orixás na metrópole. Petrópolis, RJ: Vozes, 1995, p. 41-42; Cf. DANTAS, Beatriz Góis. Vovô nagô e papai branco. Usos e abusos da África no Brasil. Rio de Janeiro: Graal, 1988. Na mesma época, Manuel Querino também fazia diferenciações semelhantes entre os africanos que viviam em Salvador. Ver: QUERINO, Manuel. A raça africana e seus os costumes. Salvador: Livraria Progresso Editora, 1955. 
e incluíam palavras em português em suas músicas, adoravam muitos santos e ainda escolhiam fetiches ao acaso. Práticas, na sua opinião, muito "degeneradas" e distantes daquelas "verdadeiras" realizadas em suas terras de origem. ${ }^{75}$

Como não era exatamente um cientista, João do Rio não parecia preocupado em encontrar soluções para o "problema racial" brasileiro. Embora não disfarçasse a simpatia que sentia por alguns de seus informantes negros, como "o grande e sábio alufá Júlio Ganam” ou o feiticeiro Benzinho Bambochê, que embaçava a humanidade com seu "admirável descaro", mas era um "ser original", fica claro que, para ele, esses africanos conformavam corpos estranhos, ultrapassados, numa cidade que caminhava para o progresso e a civilização. O que fazer, então, com esse "mundo de feitiços", que atraía desde meretrizes, ébrios e vagabundos até políticos, senhoras brancas e outros membros da "boa sociedade"? O próprio cronista, em sua derradeira descrição desse universo africano, deixa escapar uma saída. Depois de conversar com seu amigo Júlio, registrou:

Eu então caí em mim. Para que julgar os negros entes diferentes de nós? O alufá dissera com a sua imensa filosofia.

- Então você não sabe? No mundo todos querem dinheiro! Apenas há uma diferença de processos. É que os milionários brancos são as vezes mais malandros que os pretos. ${ }^{76}$

\footnotetext{
${ }^{75}$ RIO, João do. Os feiticeiros; As iaôs. In: As religiões no Rio, op. cit., p. 20, 39-40. Uma imagem bem diferente dos cabindas é apresentada por um outro escritor do período. Recordando alguns momentos de sua infância, Lima Barreto fala de Manuel de Oliveira, "cabinda de nação", que conhecera ainda menino - em fins do século XIX - quando morava na ilha do Governador. O "velho Oliveira", que sempre lhe enchera de mimos, viera "muito menino da Costa da África", comprado por um português hortelão que lhe ensinara o "ofício de plantar couves". Tinha "em grande conta sua Costa d'África". Se o escritor escarnecia de sua terra natal, o africano demonstrava um singular e geral orgulho pela África e, em particular, pela sua "nação". "Para ele, cabinda era a nacionalidade mais perfeita e superior da Terra. Nem todo negro pode ser cabinda." Certa ocasião, quando Lima Barreto lhe perguntou se um conhecido dos dois, de nome Nicolau, era cabinda, Oliveira não hesitou em responder: "- Qual o que! Aquele negro feiticeiro pode ser cabinda! Aquilo é congo ou boca de benguela." BARRETO, Lima. Manuel de Oliveira. Feiras e mafuás. São Paulo: Brasiliense, 1956, p. 224-228. Para uma análise mais detida desse texto de Lima Barreto, ver: FARIAS, Juliana B.; GOMES, Flávio S. \& SOARES, Carlos E. L. Primeiras reflexões sobre travessias e retornos, op. cit., p. 86-93.

${ }^{76}$ RIO, João do. Negros ricos. Gazeta de Notícias, 13 de maio de 1905, p. 3.
} 


\section{Referências bibliográficas}

BARBOSA, Marialva. Os donos do Rio. Imprensa, poder e público. Rio de Janeiro: Vício de Leitura, 2000.

BARRETO, Lima. Manuel de Oliveira. Feiras e mafuás. São Paulo: Brasiliense, 1956.

CANDIDO, Antonio. Formação da literatura brasileira: momentos decisivos 1750-1880. 11 ${ }^{\mathrm{a}}$ ed. Rio de Janeiro: Ouro sobre Azul, 2007. . Literatura e sociedade. São Paulo: Nacional, 1980.

CARVALHO, José Murilo. Os bestializados. O Rio de Janeiro e a República que não foi. $3^{\mathrm{a}}$ ed. São Paulo: Companhia das Letras, 1987.

COUTINHO, Afrânio (org.). A polêmica Alencar-Nabuco. Rio de Janeiro: Tempo Brasileiro, 1965.

CORRÊA, Mariza. As ilusões da liberdade: a escola Nina Rodrigues e a antropologia no Brasil. $2^{\text {a }}$ ed. revista. Bragança Paulista: Editora da Universidade de São Francisco, 2001.

DANTAS, Beatriz Góis. Vovô nagô e papai branco. Usos e abusos da África no Brasil. Rio de Janeiro: Graal, 1988.

FARIAS, Juliana B. Ardis da liberdade: trabalho urbano, alforrias e identidades. In: SOARES, Mariza de Carvalho (org.). Rotas atlânticas da diáspora africana: da Baía do Benin ao Rio de Janeiro. Niterói: Eduff, 2007, p. 225-256.

FARIAS, Juliana B.; GOMES, Flávio S. \& SOARES, Carlos Eugênio L. Primeiras reflexões sobre travessias e retornos: africanos cabindas, redes do tráfico e diásporas num Rio de Janeiro atlântico. Dossiê: História Atlântica. Textos de História. Brasília: Unb, vol. 12, n. 1/2, 2004, p. 65-105.

FARIAS, J. B., GOMES, Flávio S. e SOARES, Carlos Eugênio L. No labirinto das nações: africanos e identidades no Rio de Janeiro. Rio de Janeiro: Arquivo Nacional, 2005.

FREYRE, Gilberto. Ordem e progresso. Rio de Janeiro: Nova Aguilar, 2000.

GOMES, Renato Cordeiro. João do Rio: vielas do vício, ruas da graça. Rio de Janeiro: Relume-Dumará, Prefeitura do Rio, 1996.

GUIMBELLI, Emerson. O cuidado dos mortos: uma história da condenação e legitimação do espiritismo. Rio de Janeiro: Arquivo Nacional, 1997.

LIMA, Luís Felipe de e SODRÉ, Muniz. Um vento sagrado. História de vida de um adivinho da tradição nagô-Ketu brasileira. Rio de Janeiro: Mauad,1996.

LUSTOSA, Isabel. Insultos impressos: a guerra dos jornalistas na Independência (1821-1823). São Paulo: Companhia das Letras, 2000.

MAGALHÃES JUNIOR, Raimundo. A vida vertiginosa de João do Rio. Rio de Janeiro: Civilização Brasileira, 1978. 
MAGGIE, Yvonne. Medo do feitiço: relações entre magia e poder no Brasil. Rio de Janeiro, Arquivo Nacional, 1992.

MELLO, Maria Tereza Chaves de. A república consentida: cultura democrática e científica do final do Império. Rio de Janeiro: Editora da FGV/Edur, 2007.

O’DONNELL, Julia. De olho na rua: A cidade de João do Rio. Rio de Janeiro: Jorge Zahar Editor, 2008.

QUERINO, Manuel. A raça africana e seus os costumes. Salvador: Livraria Progresso Editora, 1955.

REIS, João José. Rebelião escrava no Brasil. A história do levante dos malês em 1835. São Paulo: Companhia das Letras, 2003 (edição revista e ampliada).

RIO, João do. As religiões no Rio. Apresentação de João Carlos Rodrigues. Rio de Janeiro: José Olympio, 2006.

. A alma encantadora das ruas. Rio de Janeiro: Secretaria Municipal de Cultura, Dep. Geral de Doc. e Inf. Cultural, 1987.

RODRIGUES, João Carlos. João do Rio: uma biografia. Rio de Janeiro: Topbooks, 1996.

RODRIGUES, Nina. Mestiçagem, degenerescência e crime. Lyon, 1899 (mimeo.)

SCHWARCZ, Lilia Moritz. O espetáculo das raças. Cientistas, instituições e questão racial no Brasil (1870-1930). São Paulo: Companhia das Letras, 1993.

SCHWARCZ, Lilia Moritz. Usos e abusos da mestiçagem e da raça no Brasil: uma história das teorias raciais em finais do século XIX. Afro-Ásia, 18, 1996.

SILVA, Wagner Gonçalves da. Orixás na metrópole. Petrópolis, RJ: Vozes, 1995.

SODRÉ, Nelson Werneck. História da imprensa no Brasil. $4^{\mathrm{a}}$ ed. Rio de Janeiro: Mauad, 1999.

Recebido: setembro/2009 - Aprovado: março/2010. 